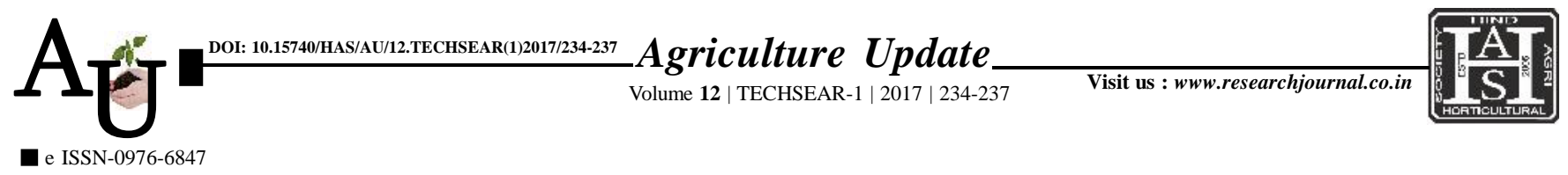

\title{
Research Article: Shelf-life study of $D p$ NPV (Nuclear Polyhedrosis Virus) suspension and formulation against larval mortality of Diaphania pulverulentalis Hampson
}

Article Chronicle : Received : 11.07.2017;

Accepted : 26.07.2017

KeY Words : $D p$ NPV, Nuclear Polyhedrosis virus, Shelf life

Author for correspondence :

\section{S. PRABHU}

Department of

Sericulture, Forest

College and Research

Institute, Tamil Nadu

Agricultural University, METTUPALAYAM (T.N.)

INDIA

Email:prabhursn@ gmail.com

See end of the article for authors' affiliations

\section{S. PRABHU, C.A. MAHALINGAM, S.V. KRISHNAMOORTHY AND R. SHUNMUGAM}

SUMMARY : Bioassay was conducted at six regular intervals (monthly once for six months) against $D$. pulverulentalis, viral suspension stored at three different temperature levels viz., refrigerated condition $\left(0 \pm 1^{\circ} \mathrm{C}\right)$, room temperature $\left(25 \pm 1^{\circ} \mathrm{C}\right)$ and high temperature $\left(35 \pm 1^{\circ} \mathrm{C}\right)$ revealed that the virus stored at high temperature $\left(35^{\circ} \mathrm{C}\right)$ readily lost its virulence with decreasing mortality from 77.92 per cent to 60.36 per cent on $5^{\text {th }}$ day, Larval mortality decreased from 78.44 per cent to 55.18 per cent on $7^{\text {th }}$ day and larval mortality decreases from 93.80 per cent to 57.92 per cent on $10^{\text {th }}$ day. The larval mortality slightly decreased at $0^{\circ} \mathrm{C}$ from 78.42 per cent to 76.95 per cent on $5^{\text {th }}$ day, 80.21 per cent to 78.45 per cent on $7^{\text {th }}$ day and 93.80 per cent to 92.23 per cent on $10^{\text {th }}$ day. The suspension which is formulated with Starch 10\% + Tinopal 0.2\% + Tween $801 \%+D p N P V @ 1 \times 10^{9} \mathrm{POB} / \mathrm{ml}$ stored at three different temperature like above mentioned levels, revealed that the virus stored at high temperature $\left(35^{\circ} \mathrm{C}\right)$ readily lost its virulence with decreasing mortality from 78.44 per cent to 55.18 per cent at $5^{\text {th }}$ day. Larval mortality decreased from 89.76 per cent to 61.67 per cent at $7^{\text {th }}$ day and 93.60 per cent to 62.65 per cent on $10^{\text {th }}$ day. The larval mortality slightly decreased at $0^{\circ} \mathrm{C}$ from 80.21 per cent to 78.45 per cent on $5^{\text {th }}$ day, 89.81 per cent to 88.21 per cent on $7^{\text {th }}$ day and 97.80 per cent to 89.88 per cent on $10^{\text {th }}$ day.

How to cite this article : Prabhu, S. Mahalingam, C.A., Krishnamoorthy, S.V. and Shunmugam, R. (2017). Shelflife study of $D p$ NPV (Nuclear Polyhedrosis Virus) suspension and formulation against larval mortality of Diaphania pulverulentalis Hampson. Agric. Update, 12(TECHSEAR-1) : 234-237; DOI: 10.15740/HAS/AU/ 12.TECHSEAR(1)2017/234-237. 